\title{
Proposal of Automation of Local Dental Anesthetics Application Process Supported by Prediction Algorithms Based on Fuzzy Logic
}

\author{
Thiago Antunes da Silva Barbosa, Polyana Vanessa Gonçalves, Milena Carvalho Tourino \\ Ribeiro, Laila Gabriela de Figueiredo Costa, Daniele Daiany da Silva Gomes, Vinicius Borges de \\ Oliveira, João Pedro Ferreira Silva, Gabriel Lavalle Garrido, Luiz Melk de Carvalho, Diva de \\ Souza e Silva Rodrigues, Flávio Henrique Batista de Souza
}

Centro Universitário de Belo Horizonte - UNIBH, Brazil

\begin{abstract}
.
Local anesthetics in dental procedures, whether simple or invasive, are found on the pharmacological market in different associations. However, its use must follow the standards requirements and the individual systemic conditions of the patient, otherwise severe complications or death may occur. Studies have demonstrated a lack of the necessary knowledge from dental surgeons and undergraduates, regarding the applicability of these drugs. Thus, this research demonstrates a proposal for an automation process, to assist in the decision making of these trained (or in training) professionals. The solution consists of a structure to collect anamnesis data, via a reception totem, from the waiting patient. With the data inserted, a sequence of rules based on Fuzzy logic, analyzes by inference with the 5 main anesthetics of the Brazilian protocol. Such inference shows the professional, according to the dosages, whether or not to treat the case. The parameters considered by the Fuzzy logic were: age of the patient; if the patient is pregnant; hypertension; diabetes; asthma; duration of the procedure; and weight (in $\mathrm{kg}$ ). The attributed results consider a combination of drugs (Lidocaine, Epinephrine, Articaine, Mepivacaine, Prilocaine, Felipressin) or the option of not treating. In addition to optimizing the waiting time in medium to large clinics, it is possible to minimize the risks of incorrect administration.
\end{abstract}

Keywords: Fuzzy, Anesthetics, Totems, Medical Errors, Health Education,

\section{Introduction}

Local anesthetics are drugs that, when in contact with nerve fibers, bind to specific receptors in the sodium channels of excitable membranes, preventing the influx of ions and consequently the spread of the stimulus. The great practical advantage of local anesthetics is the fact that their action is totally reversible, causing loss of sensation without altering the level of consciousness. After the end of the anesthetic effect, there is complete recovery of nerve function without any structural data in the cells or fibers being evident (Malamed, 2019). 
Voted one of the ten best discoveries in medicine, it made dental procedures possible with pain control. In clinical procedures, the dentist makes extensive use and administration of anesthetic solutions. They are available on the market, in various forms of concentration, both salt and vasoconstrictor. The anesthetic salt is defined according to the chemical structure of the intermediate chain, amine or ester, with those of the amine group being less toxic, with less allergenic potential. The fundamental role of the constricting vessel is to decrease toxicity and promote greater durability in the site, due to the constriction of blood vessels.

Within the clinical context, anamnesis consists of collecting information that makes it possible to raise the personal and family health history. It assists the dentist in the decisionmaking and development of the treatment plan, in addition to legally assuring the professional of any complications arising from the procedures. The use of medical records cannot be neglected, it needs to be carried out with caution to avoid future damage to the patient's health (Gruene, 2016).

Each local anesthetic has its particularity and should be indicated according to the individual systemic and physiological characteristics, as already presented. All factors described in the anamnesis must be taken into account. The concept of patients with special needs (PNEs), does not fit only individuals with physical, motor or psychic disabilities, but all those who escape the standard of normality; justifying a different approach to diabetic, hypertensive, asthmatic, pregnant women, with glandular disorders and others. Technical and practical knowledge of the employability of these drugs is extremely important, as their use without consistent scientific criteria can lead the patient to death (Medici et al, 2019).

Despite the knowledge acquired during the graduation process in the pharmacological and therapeutic disciplines, students and professionals demonstrate difficulty and knowledge below expectations. In 2011, an important study evaluated the level of knowledge of 284 dental surgeons, through a descriptive statistical analysis, it was found that $57.8 \%$ of professionals answered incorrectly to the choice of anesthetic in diabetic and pregnant patients (Caneppele et al. , 2011). However, in 2017, this scenario still remained worrying, since another cross-sectional observational study with quantitative analysis, carried out at the Integrated Faculty of Patos, in the state of Paraíba (Brazil), assessed the knowledge of 81 dental students on the same aspects. Indications were analyzed as anesthetics indicated for asthmatic patients (65.4\% were wrong and $16.0 \%$ do not know); anesthetics indicated to patients with hyperthyroidism (48.1\% Wrong and $32.1 \%$ Don't know); among others (Pontanegra et al., 2017).

A technology widely used in medical technologies, is based on Fuzzy logic, where it is possible to evaluate multiple conditions, to infer correct results (Jemal et al., 2019). This process is based on machine learning, which would make it automated to obtain valuable information for the professional's decision making (and thus reduce the errors shown).

Therefore, as the data presented are of concern, due to the complications resulting from its incorrect administration. In view of the negative results found in the literature, the project described in this paper aimed to develop prediction algorithms based on Fuzzy logic, which aim to assist in the decision-making of dentists, as well as their implementation in a digital interface in APS.NET language with NET FRAMEWORK variation, exposed through totems. For the improvement of anamnesis and digitalization of the reception of the patient until his consultation, thereby improving the conduct of the procedures and eliminating possible errors 
with anesthetic. It is characterized as a proposal that optimizes the daily life in clinics and dental offices.

\section{Methods}

\subsection{Anesthetics and risk assessment}

First, the main available local anesthetics, indications and contraindications were listed, according to Parise et al. (2017) and (Malamed (2019):

4\% of Articaine Hydrochloride + adrenaline at 1:100.000/1:200.000, intermediate duration: pulp anesthesia of about 60 minutes. Local anesthetic with amide binding. Its plasmatic halflife is lower than that of most other amide type anesthetics, which, among other factors, would be theoretically favorable in relation to systemic toxicity. he potential side effect of administering large doses of articain is metahemoglobinemia, a reaction perceived after accidental intravenous administration when performing regional anesthesia, but no cases were reported when administering the correct volume for dental procedures.

$0.5 \%$ of Bupivacaine hydrochloride + adrenaline at 1:200.000, long duration: pulp anesthesia of more than 90 minutes. This is the only anesthetic salt that provides long duration of anesthesia in soft tissues in both arches and pulp of mandibular teeth, lasting from 2 to 5 hours after an epidural injection and up to 12 hours in peripheral nerve blocks. It is a very important local anesthetic in the prevention of postoperative pain and when administered in conjunction with nonsteroidal anti-inflammatories the postoperative period becomes more comfortable. In elderly patients, bupivacaine is the last option to be considered, due to its long duration, and when it is used, it should be used with a low concentration constrictor vessel (adrenaline 1:200,000) and should not exceed the equivalent of that contained in 2 anesthetic tubes, and normally 1 tube is sufficient for most dental interventions in these patients.

$2 \%$ of Lidocaine hydrochloride + adrenaline at 1:100.000, intermediate duration: pulp anesthesia of about 60 minutes. Commercial preparations of lidocaine with or without adrenaline association are available on the market. The adrenaline doses can be find in concentrations of $1: 50,000,1: 80,000$ and $1: 100,000$. It is rapidly metabolized by microsomal oxidation in the liver. Its elimination is renal, and $10 \%$ are excreted unchanged. Allergic reactions to this drug are extremely rare. Lidocaine is the safest anesthetic for pregnant women, as it is associated with 1:100,000 adrenaline, with a maximum of 2 doses per session. It is also safe for use in children, with adrenaline at 1:200,000, the maximum dose being with or without vasoconstrictor one anesthetic tube for every $9.09 \mathrm{~kg}$.

$2 \%$ of Mepivacaine hydrochloride + levonordephrin at 1:20.000, intermediate duration: pulp anesthesia of about 60 minutes. This anesthetic agent, belonging to the group of amides, is characterized by being metabolized in the liver and having its final products excreted by the kidneys, where approximately $1 \%$ to $16 \%$ of the applied dose is excreted unchanged. Despite the discrete vasodilator property, mepivacaine without vasoconstrictor has an anesthetic effect duration of 20 to 40 minutes, showing greater efficiency when compared to lidocaine without vasoconstrictor, which has a duration of approximately 5 minutes. On the other hand, when associated to the vasoconstrictors, the duration of the anesthetic action is more extensive, reaching periods of 3 to 5 hours of local anesthesia. There are three vasoconstrictors 
associated with mepivacaine: levonordephrine (1:20,000), noradrenaline $(1: 100,000)$ and adrenaline $(1: 100,000)$. Although there is hemostasis, levonordephrin and noradrenalin do not produce the intensity of hemostasis observed with adrenalin. It has pharmacological characteristics similar to lidocaine, but it is distinguished by producing only vasodilation and can be used without vasoconstrictor in short procedures..

$4 \%$ of Prilocaine Chloride + adrenaline at 1:200.000, intermediate duration: pulp anesthesia of about 60 minutes and is similar to lidocaine. It is less toxic, but also less potent than lidocaine, and so it is used in concentrations of $4 \%$ instead of $2 \%$ of lidocaine, but the actual toxicity is quite similar. The vasoconstrictor can be adrenaline at $1 / 200,000$ or felipressin in concentrations of $0.03 \mathrm{IU} / \mathrm{ml}$. Felipressin, a synthetic hormone similar to vasopressin and constituent of anesthetic solutions whose salt is prilocaine, does not act on adrenergic receptors, therefore, it does not produce significant changes in heart rate. At low concentrations, it does not increase the intravenous toxicity of prilocaine solutions. Ischemia produced by it is not followed by tissue hypoxia, as occurs with adrenaline and noradrenaline. Felipressin should not be used in pregnant women because it is related to oxytocin, which has the potential to cause uterine contractions.

\subsubsection{Assessment of the correct use of local anaesthetics}

Some factors are relevant for the correct use of local anesthetics, such as the duration of the pulp and soft tissue anesthesia, because the action of pain control should last throughout the period of dental care. The correct dosage of anesthetic according to the patient's weight is also of paramount importance, along with the observation of contraindications for its use and some clinical conditions (Malamed, 2019). The anesthesia can be short (30 minutes), intermediate (60 minutes) or long (90 minutes), which will depend on the type of anesthetic and the type of vasoconstrictor present in the doses. Table 1 shows the duration of local anesthetics.

Table 1: Local anaesthetics dosages

\begin{tabular}{|l|l|l|}
\hline \multicolumn{2}{|c|}{ Pulpal anesthesia duration } \\
\hline Short (30 minutes) & Intermediate (60 minutes) & Long ( >90 minutes) \\
\hline 3\% of Mepivacaine & $\begin{array}{l}\text { Articaine at 4\% + adrenaline } \\
\text { at } 1: 100.000 .\end{array}$ & $\begin{array}{l}\text { Bupivacaine at 0.5\% + adrenaline at } \\
1: 200.000 \quad \text { by nerve block) }\end{array}$ \\
\hline $\begin{array}{l}\mathbf{4 \%} \text { of Prilocaine } \\
\text { (by infiltration) }\end{array}$ & $\begin{array}{l}\text { Articaine at 4\% + adrenaline } \\
\text { at 1:200.000 }\end{array}$ & \\
\hline & $\begin{array}{l}\text { Lidocaine at 2\%+ adrenaline } \\
\text { at 1:50.000 }\end{array}$ & \\
\hline & Lidocaine at 2\%+ adrenaline at 1:100.000 & \\
\hline & $\begin{array}{l}\text { Mepivacaine at 2\% + levonordephrin at } \\
1: 20.000\end{array}$ & \\
\hline & Prilocaine at 4\% (only by nerve block) & \\
\hline & Prilocaine at 4\% + adrenaline at 1:200.000 & \\
\hline
\end{tabular}

Source: (Authors)

If the dentist uses an anesthetic with the wrong time this may bring trauma to the patient. Using an anesthetic with a short period for an intermediate or long procedure will cause the patient to feel pain before the end of the procedure generating a trauma to the patient. Using a long-term anesthetic for a procedure that will last for a short period of time will also bring problems, when related to its use in children, elderly patients and people with mental or physical disabilities, because they can bite or chew your tongue, lips and cheek. This error 
also affects individuals with type I diabetes, as they need to feed themselves to maintain favorable glucose levels in their bodies and anesthesia of the soft tissues will make it difficult to eat.

Another relevant factor in the application of local anaesthetic is the dose to be administered to each patient. The calculation of the recommended amount in the dose is different for each local anesthetic and vasoconstrictor present. Such calculation is made with the maximum dose per milligram multiplied by the weight then divided by the amount of lidocaine present in one dose.

$\frac{\text { Maximum Dose fmgXweighit }}{\text { fmer }}=$ Recommended amount of doses

Table 2 shows each local anaesthetic with its allowed doses per $\mathrm{Kg}$ and the maximum recommended dose (DMR), which is the maximum dose that can be given to the patient regardless of their weight being high (Malamed, 2019).

Table 2: Local anesthetics dosages

\begin{tabular}{|l|l|l|l|l|}
\hline $\begin{array}{l}\text { Local } \\
\text { Anesthetic } \\
\text { local }\end{array}$ & Vasoconstrictor & Dose mg/kg & $\begin{array}{l}\text { Amount of } \\
\text { Anesthetic per dose }\end{array}$ & DMR, mg \\
\hline Articaine & with vasoconstrictor & 7.0 & 72 & \\
\hline Bupivacaine & with vasoconstrictor & 2.0 & 36 & 90 \\
\hline Lidocaine & with vasoconstrictor & 7.0 & 36 & 500 \\
\hline \multirow{2}{*}{ Mepicaiva } & $\begin{array}{l}\text { without } \\
\text { vasoconstrictor }\end{array}$ & 6.6 & 54 & 400 \\
\cline { 2 - 6 } & with vasoconstrictor & 6.6 & 54 & 400 \\
\hline Prilocaine & $\begin{array}{l}\text { without } \\
\text { vasoconstrictor }\end{array}$ & 8.0 & 72 & 600 \\
\cline { 2 - 6 } & with vasoconstrictor & 8.0 & 72 & 600 \\
\hline
\end{tabular}

Source: (Authors)

An exacerbated dose of any local anaesthetic can generate an overdose in the patient's body, which presents some signs and symptoms such as: vomiting, inability to respond to commands, high blood pressure, high heart rate, high respiratory rate, convulsions and in more severe cases can lead to death. Therefore, it is of utmost importance to administer the correct dose of local anaesthetics. The contraindication of a certain local anaesthetic and vasoconstrictor is also a relevant factor during its choice. Therefore, it is important to pay attention to the medical problems of the patient, the contraindications and alternative substances that can be used by these patients. Table 3 shows some contraindications and alternative substances (Malamed, 2019). Some clinical conditions also have an influence on the time of choice of the local anaesthetic such as hypertension, age, diabetes, asthma and pregnancy.

Table 3: Indications and contraindications due to some medical problems

\begin{tabular}{|l|l|l|}
\hline \multicolumn{1}{|c|}{ Medical Problems } & \multicolumn{1}{|c|}{ contraindications } & \multicolumn{1}{c|}{ Alternative Substances } \\
\hline Proven allergy & Anesthetics of the same chemical class & Anesthetics of another chemical class \\
\hline Bissuffite allergy plasma & Local anesthetics with vasoconstrictor & Anesthetic without vasoconstrictor \\
\hline $\begin{array}{l}\text { Atypical } \\
\text { cholinesterase }\end{array}$ & Amides \\
\hline $\begin{array}{l}\text { Metahemoglobinemia, } \\
\text { idiopathic or congenital }\end{array}$ & Prilocaine & Other amides or esters \\
\hline
\end{tabular}


11th International Conference on Research in

ENGINEERING, SCIENCE \& TECHNOLOGY

Budapest, Hungary

19-21 March, 2021

\begin{tabular}{|l|l|l|}
\hline $\begin{array}{l}\text { Significant liver } \\
\text { dysfunction (ASA 3-4) }\end{array}$ & Amides & Amides or esters \\
\hline $\begin{array}{l}\text { Significant renal } \\
\text { dysfunction }\end{array}$ & Amides or esters & \\
\hline $\begin{array}{l}\text { Significant cardiovascular } \\
\text { disease }\end{array}$ & High concentrations of vasoconstrictors & $\begin{array}{l}\text { Anaesthetics with adrenaline } \\
1: 200,000 \text { or } 1: 100,000, \text { mepivacaine } \\
3 \% \text { or prilocaine 4\% (nerve block) }\end{array}$ \\
\hline Clinical hyperthyroidism & High concentrations of vasoconstrictors & $\begin{array}{l}\text { Anaesthetics with adrenaline } \\
1: 200,000 \text { or } 1: 100,000, \text { mepivacaine }\end{array}$ \\
& & $3 \%$ or prilocaine 4\% (nerve block) \\
\hline
\end{tabular}

Source: (Authors)

\subsection{Development Methodology and Experiments}

The basic purpose of the tool was to describe often vague data and transform it into information that can be applied in research, theses and, as presented in this work, serve as a query for which decision to make in the daily life of a dental clinic.

Thus, first a reference anamnesis was defined, described in Appendix I, and practiced in a real clinic. Then a structure proposal was developed, both in terms of software and hardware to evaluate the data entered in the anamnesis and submission to the analysis process by fuzzy logic. Finally, an evaluation of 3 cases was performed to validate the Fuzzy inferences.

\section{Results}

\subsection{Proposal of the developed structure}

\subsubsection{Definition of the sequence of operation of the structure}

The basic purpose of the tool was to transform the data available into information that can be applied in researches and serve as a query to help the decision-making in the daily life of a dental clinic. Figure 1 shows the sequence of the data processing from entry to decision making by the health professional.

Figure 1. Application of Fuzzy inferences in the decision-making process of drug applications in patientswith their respective informational conditions.

\begin{tabular}{|l|}
\hline Entry of Patient Information:Via Totem \\
\hline $\begin{array}{l}\text { Inferences formed through reprocessing: Output of } \\
\text { inferences through comparative graphs. }\end{array}$ \\
\hline Graphics projection: Via monitor screen. \\
\hline Professional Decision Making \\
\hline
\end{tabular}




\subsubsection{Definition of the Fuzzy Rules}

The data used for the analysis and description of the tool procedure were age, pregnancy, hypertension, diabetes and asthma. Such information was chosen because of the degree of risk if an anesthetic and vasoconstrictor were mistakenly applied.

The Fuzzy attributions were: the age of the patient considering from 0 to 12 years as children, from 13 to 59 as adults and from 60 to 100 years elderly; pregnancy, considering 0 for not pregnant and 1 for pregnant; hypertension considering0 for non-hypertensive, 0.5 for controlled hypertensive and 1for non-controlled hypertensive people; for diabetes was considered 0 for non-diabetic 0.5 for controlled diabetic and 1 for non-controlled diabetic people; for asthmawas considered 0 for patients without asthma and 1 for patients with asthma; Duration of the procedure considered between 0 and 90 minutes; weight considered between 1 and $200 \mathrm{~kg}$. The attributed results were: $0=$ Lidocaine $2 \%+$ Epinephrine 1:100.000; $0.2=$ Articaine 4\%; $0.4=$ Mepivacaine 3\%; $0.6=$ Prilocaine 4\% + Felipressin; 0.8 $=$ no treatment and the dose of each anesthetic.

The correct anesthetic for pregnant women is lidocaine $2 \%$ with epinephrine 1:100.000. Using this data to formulate the fuzzy logic: by inserting in the field pregnancy: yes and not in the rest of the fields; the result being: $0=$ Lidocaine $2 \%+$ Epinephrine $1: 100.000$.

The correct anesthetic for controlled hypertensive people is mepivacaine, so formulating the fuzzy logic: by inserting in the hypertension field: controlled; in the field age: adult; and not in the remaining fields; the result is $0.4=$ Mepivacaine 3\%. For uncontrolled hypertensive people the right thing to do is not to treat them, so this rule was added to the fuzzy logic: in the field non-controlled hypertension; the result is $0.8=$ no treatment. The recommended local anesthetic for those with controlled diabetes is Prilocaine $4 \%$ with the vasoconstrictor felipressin , adding this data to formulate the Fuzzy logic: in the field diabetes: controlled; the result is $0.6=$

Prilocain $4 \%$ + felipressin. In non-controlled diabetes the indicated is to use Mepivacaine3\%, adding this logic to Fuzzy: in the filed diabetes: non-controlled; the result is: $0.4=$ Mepivacaine 3\%.

In asthmatics the correct is to use prilocaine $4 \%$ with felipressin, adding this logic to the fuzzy: in the field asthma: yes; the result is: $0.6=$ Prilocaine $4 \%+$ Felipressin. In children the right thing to do is to use lidocaine $2 \%$ with epinephrine $1: 100.000$, disregarding all other fields in the logic: in the field age: from 0 to 12; the results is: $0=$ lidocaine + Epinephrine. In elderly patients the right thing to do is to administer the Artcaine4\%, adding the logic in the field age between 60 and 100 years; the result is: $0.2=$ Articane $4 \%$. Table 4 shows some of the correlations used in fuzzy logic to give the ideal anesthetic result for each patient.

Table 4: Fuzzy results reference

\begin{tabular}{|l|l|l|l|l|l|l|l|l|}
\hline Pregnancy & Hypertension & Diabetes & Asthma & Age & $\begin{array}{l}\text { Weight } \\
\text { Duration } \\
\text { of } \begin{array}{l}\text { Recommended } \\
\text { procedure }\end{array}\end{array}$ & $\begin{array}{l}\text { Recommended } \\
\text { dose }\end{array}$ \\
\hline Yes(1) & No(0) & No(0) & No(0) & - & - & $\begin{array}{l}60 \\
\text { minutes }\end{array}$ & $\begin{array}{l}2 \% \text { Lidocaine } 2 \text { tubetes } \\
\text { with adrenaline } \\
1: 100,000(0)\end{array}$ & \\
\hline No(0) & $\begin{array}{l}\text { Yes, } \\
\text { controlled }(0,5)\end{array}$ & No(0) & No(0) & 45 & $50 \mathrm{~kg}$ & $\begin{array}{l}60 \\
\text { minutes }\end{array}$ & $\begin{array}{l}\text { Prilocaine } 4 \% \\
\text { with felipressin }\end{array}$ & 5 tubes \\
\hline
\end{tabular}


11th International Conference on Research in

ENGINEERING, SCIENCE \& TECHNOLOGY

\begin{tabular}{|c|c|c|c|c|c|c|c|c|}
\hline & & & & & & & $(0.6)$ & \\
\hline $\mathbf{N o}(\mathbf{0})$ & $\begin{array}{l}\text { Yes, } \\
\text { Not controlled(1) }\end{array}$ & $\mathrm{No}(0)$ & $\operatorname{No}(0)$ & 45 & $50 \mathrm{~kg}$ & - & Do not treat $(0.8)$ & \\
\hline No(0) & $\mathrm{No}(0)$ & $\begin{array}{l}\text { Yes, } \\
\text { controlled }(0,5)\end{array}$ & $\mathrm{No}(0)$ & 45 & $50 \mathrm{~kg}$ & $\begin{array}{l}60 \\
\text { minutes }\end{array}$ & $\mid \begin{array}{ll}\text { Prilocaine } & 4 \% \\
\text { with } & \text { felipressin } \\
(0.6) & \end{array}$ & 5 tubes \\
\hline$\overline{\operatorname{No}(0)}$ & $\mathrm{No}(0)$ & $\begin{array}{l}\text { Yes, no } \\
\text { Controlled (1) }\end{array}$ & $\mathrm{t} \mathrm{No}(0)$ & 45 & $50 \mathrm{~kg}$ & $\begin{array}{l}30 \\
\text { minutes }\end{array}$ & $\begin{array}{l}\text { Mepivacaine 3\% } \\
(0.4)\end{array}$ & 6 tubes \\
\hline $\mathbf{N o}(\mathbf{0})$ & $\mathrm{No}(0)$ & $\mathrm{No}(0)$ & & 45 & $50 \mathrm{~kg}$ & $\begin{array}{l}60 \\
\text { minutes }\end{array}$ & 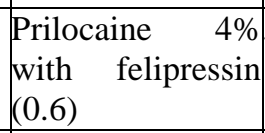 & 5 tubes \\
\hline $\operatorname{No}(\mathbf{0})$ & $\mathrm{No}(0)$ & $\mathrm{No}(0)$ & $\mathrm{No}(0)$ & 65 & $60 \mathrm{~kg}$ & $\begin{array}{l}60 \\
\text { minutes }\end{array}$ & $\begin{array}{l}\text { Articaine } \\
(0.2)\end{array}$ & 5 tubes \\
\hline $\operatorname{No}(\mathbf{0})$ & $\mathrm{No}(0)$ & $\mathrm{No}(0)$ & $\operatorname{No}(0)$ & 10 & $11 \mathrm{~kg}$ & $\begin{array}{l}60 \\
\text { minutes }\end{array}$ & $\begin{array}{lr}2 \% & \text { Lidocaine }+ \\
1: & 100,000 \\
\text { adrenaline }(0)\end{array}$ & 2 tubes \\
\hline
\end{tabular}

Source: (Authors)

\subsubsection{Development of the totem structure}

The work done involves an application development for user interface, a hardware definition for the totem and the development of the fuzzy logic to analyse the patient anamnesis.

The application was developed in APS.NET programming language with variation.NET FRAMEWORK (Microsoft Visual Studio IDE), being integrated into a database of the Microsoft SQL Management Studio 2008 R2 (Future development of this database to store more information).

The hardware specifications were: Processor: 32 bits (x86) or 64 bits (x64) with $1 \mathrm{GHz}$ or superior; Memory RAM: 1 GB of RAM (32 bits) or 2 GB of RAM (64 bits); HD: 16 GB (32 bits) or $20 \mathrm{~GB}$ (64 bits) space available in disk; and operational system: Windows 7 Professional or superior.

In addition to the settings, an overview specification of the totem structure was required, as shown in Figure 2. Finally, the user interfaces, described in Appendix II, were developed with the respective user interaction screens. 
Figure 2: Physical totem model, with dimensions of: $1.8 m$ Height and 0.6m Width.

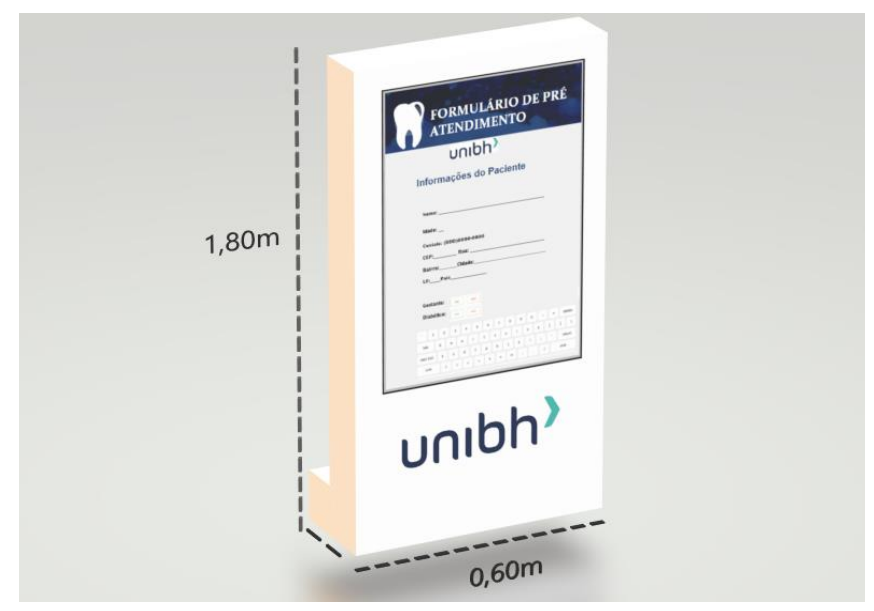

Source: (Authors)

\subsection{Clinical experimentation of the Fuzzy logic}

To demonstrate the effectiveness of fuzzy logic results, some clinical cases were presented, entering their data and obtaining the result by fuzzy. Case 1: Female patient, 47 years old, weighs $60 \mathrm{~kg}$, with indication of removal of the root remains of element 14. In her anamnesis, she reported being a type II diabetic using daily insulin. The physical examination showed $\mathrm{PA}=13 \mathrm{X} 80 \mathrm{MMHG}$ and glycemia $=89 \mathrm{mg} / \mathrm{dl}$.

Case 2: Female, 25 years old, $60 \mathrm{~kg}$, with indication for endodontic treatment of element 36. In her anamnesis she reported being in the third month of pregnancy, reported absence of comorbidity and denied the use of medication. Radiographic examination showed a periapical lesion. The physical examination showed PA $=120$ X80 MMHG.

Case 3: Male patient, 35 years old, $80 \mathrm{~kg}$ with indication of exodontia of 37. At anamnesis, he reported being a carrier of contralateral systemic arterial hypertension, diagnosed 4 years ago. At the physical examination, he presented PA= 14X10 MMHG. Radiographic clinical examination showed extensive coronary destruction with endodontic treatment.

The results of the anesthetics and number of doses obtained by fuzzy were those expected and indicated for each individuality and clinical condition of the patients, according to the data presented (table 5).

Table 5: Results from the data provided to the fuzzy:

\begin{tabular}{|c|}
\hline $\begin{array}{l}\text { No }(0)+\mathrm{No}(0)+\text { Yes, Under Control }(1)+\mathrm{No}(0)+50 \text { Years+60Kg+60Minutes }=\text { Prilocaine } 4 \% \text { With Felipressin } 5 \\
\text { Tubets }\end{array}$ \\
\hline $\begin{array}{l}\text { Yes }(1)+\mathrm{No}(0)+\mathrm{No}(0)+\mathrm{No}(0)+25 \mathrm{Years}+60 \mathrm{Kg}+60 \mathrm{Minutes}=2 \% \text { Lidocaine with adrenaline 1: 100,000 (0) } 2 \\
\text { Tubets }\end{array}$ \\
\hline $\begin{array}{l}\text { No }(0)+\text { Yes, Under Control }(0.5)+\mathrm{No}(0)+\mathrm{No}(0)+35 \text { Years+80Kg+60Minutes }=\text { Prilocaine } 4 \% \text { with felipressin } 8 \\
\text { tubes }\end{array}$ \\
\hline
\end{tabular}

\section{Conclusion}

With the preparation and implementation of the project, it was found that the FUZZY inferences attributed to digital anamnesis obtained highly significant and assertive results in 
terms of anesthetic employability. In addition there is also the time optimization at the data collection stage. It contributes to the advancement of dentistry, has the potential to assist the dentist in decision-making, significant reduction of toxicity, overdose, circulatory problems and misuse.The pharmaceutical industry has developed over time to meet the systemic needs of each patient. Local anesthetics adapted to the dental environment, allows pain and discomfort control during the procedures performed every day, in several offices and clinics around the world. Its use, associated or not with constrictor vessels, when poorly employed can lead to death. The level of knowledge of dentists and students is below that expected when the applicability. Therefore, the scientific issue raised in this work is the recognition of technology as an indispensable instrument for dental medical science, intermediating on the prescriptive anesthetic basis.

With the execution of the project, the data received in the survey has proved satisfactory. The FUZZY assignment allows the gathering of relevant information in decision making, such as: age, pregnancy, hypertension, diabetes, asthma, procedure duration and weight, through prediction algorithms and similarity of results, goes beyond the affirmatives yes and no, generates results. Within the perspective presented, the results applied to fictitious clinical cases presents the platform, as a reliable and practical tool, with a relevant assertiveness, in anesthetic salt, constrictor vessel and dosage.

\section{References}

[1] Malamed, S. F. (2019). Handbook of Local Anesthesia, 7e: South Asia Edition-E-Book. Elsevier India.

[2] Parise, G. K.; Ferranti, K. N. and Grando, C. P. (2017) Sais Anestésicos Utilizados na Odontologia: Revisão De Literatura. Journal Of Oral Investigations, V. 6, N. 1, P. 75-84.

[3] Gruene, S. (2016). Anamnesis and clinical examination. Deutsche medizinische Wochenschrift (1946), 141(1), 24-27.

[4] Medici, S., Peana, M., Nurchi, V. M., and Zoroddu, M. A. (2019). Medical uses of silver: history, myths, and scientific evidence. Journal of medicinal chemistry, 62(13), 59235943.

[5] Caneppele, T. M. F., Yamamoto, E. C., Souza, A. C., Valera, M. C., \& Araújo, M. A. M. (2011). Conhecimento dos cirurgiões-dentistas sobre o atendimento de pacientes especiais: hipertensos, diabéticos e gestantes. Journal of Biodentistry and Biomaterials, São Paulo, 1, 31-41.

[6] Pontanegra, R. S. M., de Lucena Camboim, C. C., Freire, J. C. P., Nóbrega, M. T. C., Barreto, J. O., dos Santos, J. A., and Dias-Ribeiro, E. (2017). Análise do conhecimento de Graduandos em Odontologia sobre o uso de anestésico local em pacientes com necessidades especiais. Revista da Faculdade de Odontologia de Lins, 27(1), 5-14.

[7] Jemal, H., Kechaou, Z., and Ben Ayed, M. (2019). Multi-agent based intuitionistic fuzzy logic healthcare decision support system. Journal of Intelligent \& Fuzzy Systems, 37(2), 2697-2712. 
11th International Conference on Research in

ENGINEERING, SCIENCE \& TECHNOLOGY

Budapest, Hungary

19-21 March, 2021

Appendix : Anamnesis of Reference

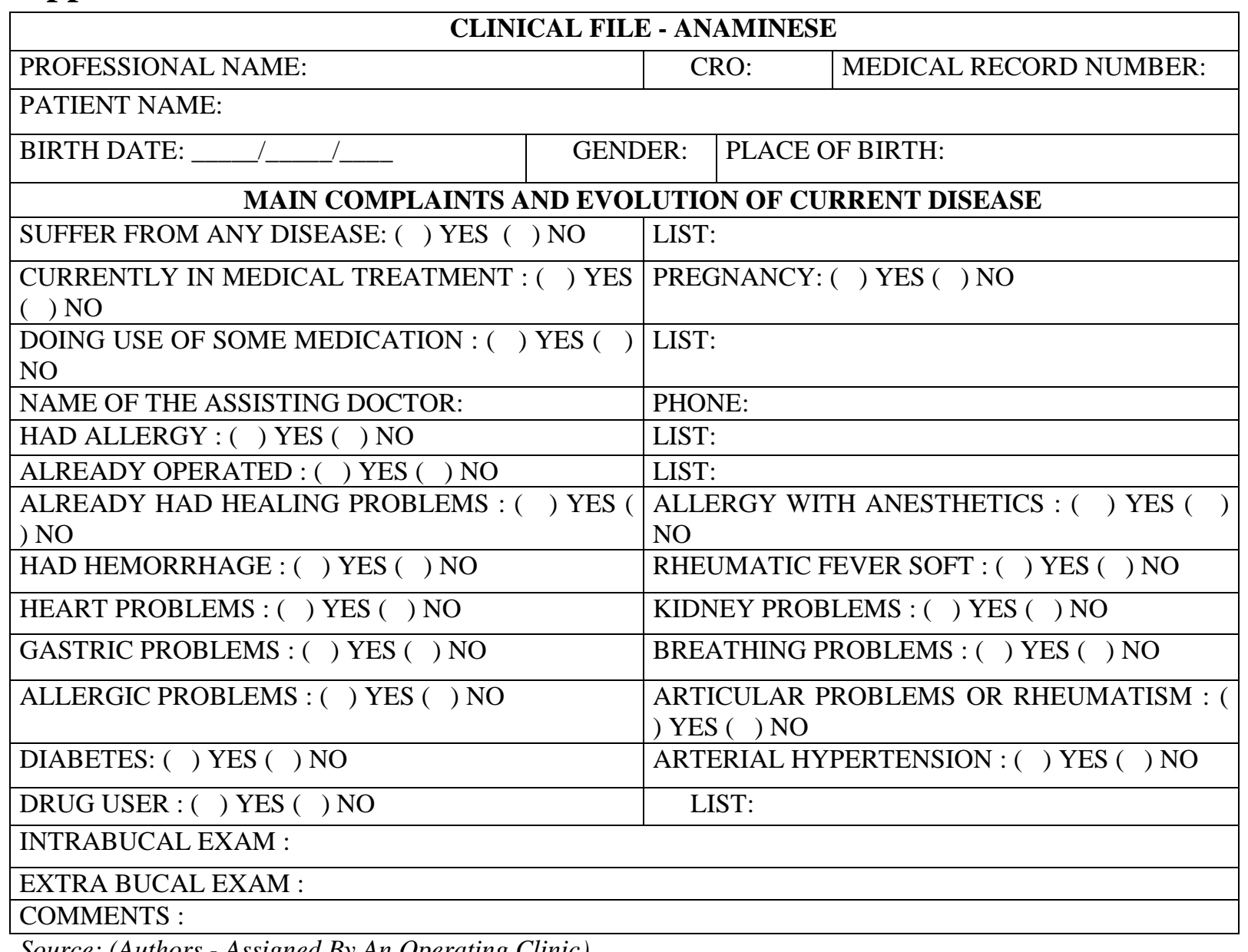

Source: (Authors - Assigned By An Operating Clinic)

Appendix II: Example of User Interfaces (Screenshots in Portuguese)
a. Welcome screen
b. Confirmation (final screen) 
11th International Conference on Research in

ENGINEERING, SCIENCE \& TECHNOLOGY

Budapest, Hungary

19-21 March, 2021

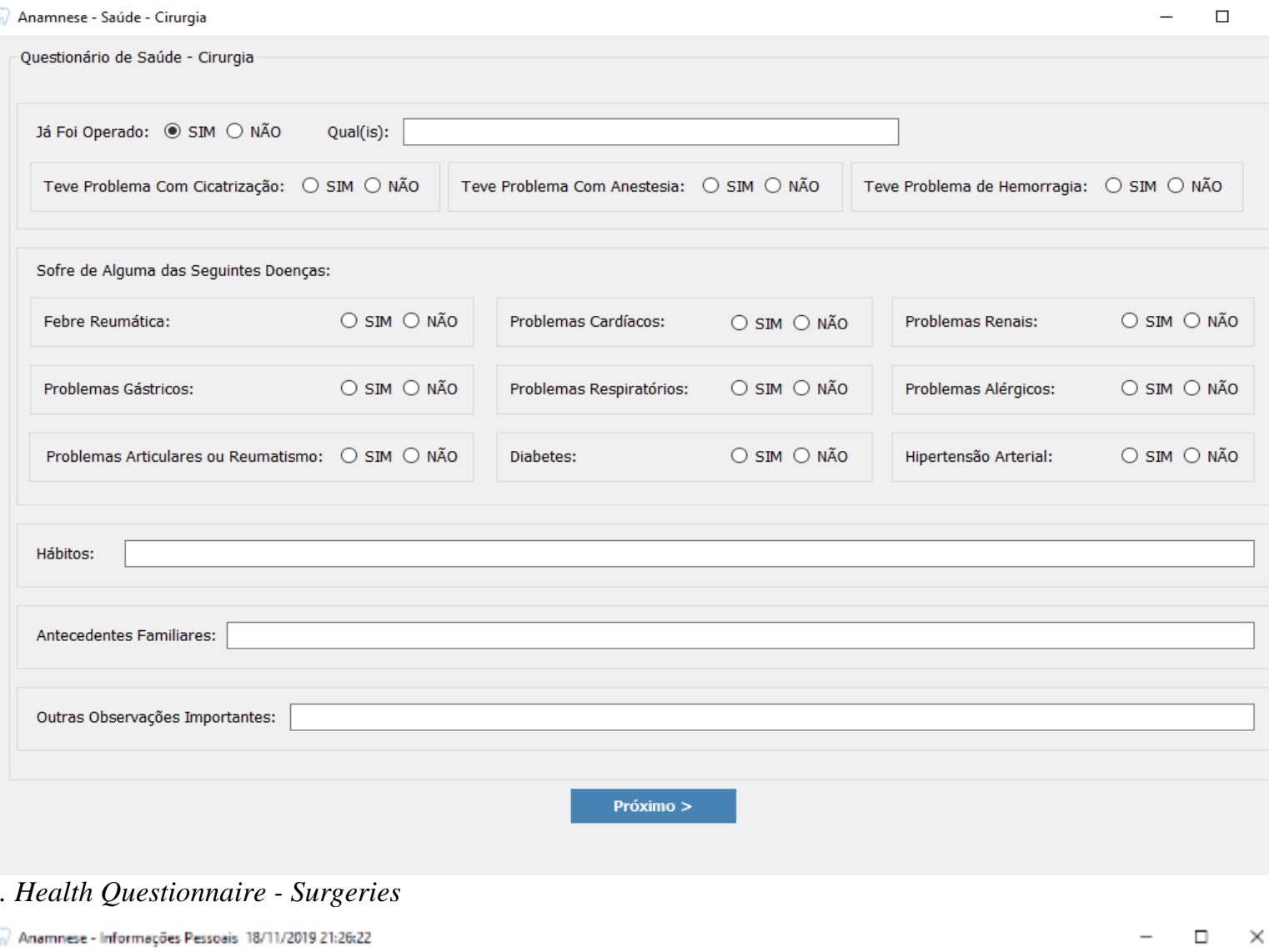

W7 Anamnese-Informeçōes Pessosis 18/11/2019 21:26:22

Informeçōes Pessozis

Nome:

RC. $n^{0}$ :

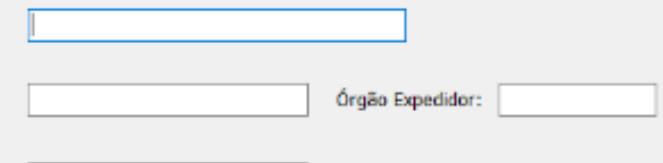

GrF.n*:

Nascimento?

Sexo:

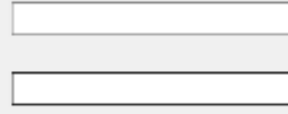

Estado Cwil:

Conjuge:

OM OF

RG. $n^{\circ}$ :

Naturalidade:

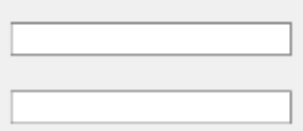

Órgăo Expedidor:

CPF. no:

Nascionalidade

Endereço Residencial:

Endereço Profissional: 
11th International Conference on Research in

\section{ENGINEERING, SCIENCE \& TECHNOLOGY}

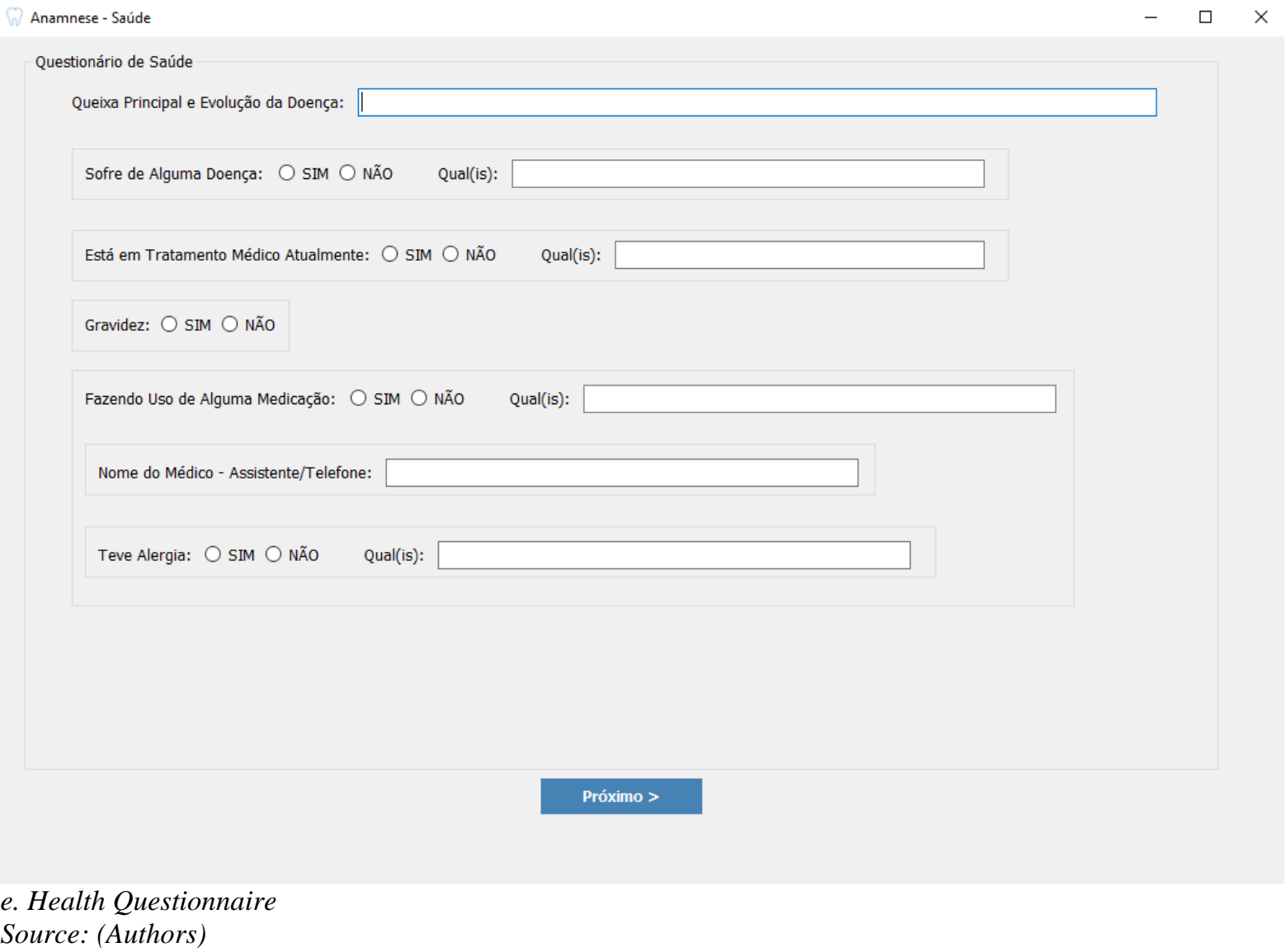

